Artículo científico

Volumen 31(1): 141-156. Enero-abril, 2020

e-ISSN 2215-3608, doi:10.15517/am.v31i1.37062

http://www.revistas.ucr.ac.cr/index.php/agromeso

\title{
Herd management information systems to support cattle population research: the VAMPP ${ }^{\circledR}$ case $^{1}$
}

\section{Sistemas de gestión de hato para apoyar investigación en poblaciones ganaderas: el caso VAMPP®}

\author{
Z. Sánchez-Hernández ${ }^{2}$, C.S. Galina-Hidalgo², B. Vargas-Leitón ${ }^{3}$, J. Rojas-Campos ${ }^{3}$, S. Estrada-König ${ }^{3}$
}

1 Reception: April 30 $0^{\text {th }}, 2019$. Acceptance: July 18 ${ }^{\text {th }}$, 2019. This work was part of the MSc. Thesis in Sustainable Animal Production of the first author at Program of Master's and Doctorate in Animal Health Production Sciencies, Universidad Nacional Autónoma de México, Mexico city, Mexico.

2 Universidad Nacional Autonoma de Mexico, Faculty of Veterinary Medicine and Zooctechnics, Department of Reproduction, Mexico city, Mexico.zazhilsnxz@gmail.com, cgalina@unam.mx

3 Universidad Nacional, School of Veterinary Medicine, Research Program in Population Medicine, P.O. Box: 304-3000, Heredia, Costa Rica. bernardo.vargas.leiton@una.cr (corresponding author; https://orcid.org/0000-0002-1778-9672). jose.rojas.campos@una.cr, sandra.estrada. konig@una.cr

\begin{abstract}
Introduction. Livestock information systems, besides being indispensable for the daily management of the herd, can serve as a basis for research at the population level. Objective. The objective of the study was to analyze the role of the VAMPP ${ }^{\circ}$ system as a source of information for cattle population research over 32 years of evolution in Costa Rica. Materials and methods. A statistical analysis of the system database (VAMPP®) covering the period between 1987 and 2018 was carried out. Trends in the dissemination and adoption of the system were evaluated according to period, area, production system, and herd size. The use of information for the exploration of trends by breed and area was exemplified. The contribution of the system at the academy level and production of scientific literature was quantified. Results. 2285 herds ( $88.8 \%$ specialized dairy and $11.2 \%$ dual purpose) were counted with an average of $9.4 \pm 7.9$ years of follow-up in the VAMPP® system. The areas with greater diffusion were the very humid premontane forest $(29 \%)$ and very humid tropical forest $(25 \%)$. The average size of the herd was $124 \pm 255$ adult cows. The system contains records on 404316 cows, mostly of Holstein (36.3\%), Jersey (24.6\%), and Holstein $\times$ Jersey (20.9\%) breeds. The database includes information on 1,249,557 calvings, 16,223,260 records of daily milk production, and 443,108 health events, predominantly related to mastitis $(35.6 \%)$ and laminitis $(14.1 \%)$. The system has been used for the elaboration of at least 74 investigations leading to academic degrees and the production of 71 scientific articles, mainly related to health and genetic issues. Conclusion. The information obtained from the VAMPP® system has allowed a detailed characterization of the productive performance of local dairy cattle.
\end{abstract}

Keywords: information technology, dairy cattle, tropical zones. 


\section{Resumen}

Introducción. Los sistemas de información ganadera, además de ser indispensables para el manejo diario del hato, pueden servir de base para la investigación a nivel poblacional. Objetivo. El objetivo del estudio fue analizar el rol del Sistema VAMPP® como fuente de información para la investigación en poblaciones bovinas a lo largo de 32 años de evolución en Costa Rica. Materiales y métodos. Se realizó un análisis estadístico de la base de datos del sistema (VAMPPß) en Costa Rica, que abarcó el periodo entre 1987 y 2018. Se evaluaron tendencias en diseminación y adopción del sistema según periodo, zona, sistema de producción, y tamaño del hato. Se ejemplificó el uso de la información para la exploración de tendencias por raza y zona. Se cuantificó el aporte del sistema a nivel de academia y producción de literatura científica. Resultados. Se contabilizaron 2285 hatos $(88,8 \%$ de lechería especializada y 11,2

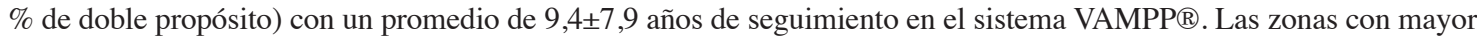
difusión fueron el bosque muy húmedo premontano (29\%) y bosque tropical muy húmedo (25\%). El tamaño promedio de los hatos fue de $124 \pm 255$ vacas adultas. El sistema contiene registros sobre 404316 vacas, mayoritariamente de razas Holstein (36,3 \%), Jersey (24,6 \%) y Holstein×Jersey (20,9\%). La base de datos incluye información sobre 1249 557 eventos de parto, 16223260 registros de producción diaria de leche y 443108 eventos de salud, entre los cuales predominan eventos de mastitis $(35,6 \%)$ y laminitis $(14,1 \%)$. El sistema ha sido utilizado para la elaboración de al menos 74 investigaciones conducentes a grados académicos y la producción de 71 artículos científicos, principalmente relacionados con temas de salud y genética. Conclusión. La información obtenida a partir del sistema VAMPP ha permitido realizar una detallada caracterización del rendimiento productivo del ganado lechero local.

Palabras clave: tecnología de la información, ganado lechero, zona tropical.

\section{Introduction}

The Information Technologies (IT) became a highly important tool since the 90s, when the expression "economy based in knowledge" took a place in the modern economic life. The expression references the growing dependency of companies' successes together with countries' economies in the effectiveness of IT to generate and apply knowledge (Vilaseca et al., 2002; Pérez et al., 2006). Agriculture has entered a new era in which the key to success is access to timely information and elaborated decision making. Farm Management Information Systems (FMIS) have evolved from simple farm recordkeeping into sophisticated and complex systems to support production management (Fountas et al., 2015; Tsiropoulos et al., 2017).

Population research has been an essential tool in different areas of animal production, such as epidemiology and animal breeding. The study of animal performance directly in the production sites is essential for a more comprehensive understanding of the productive processes. Farm-based Livestock Information Systems (LIS) can provide an effective and low-cost source of information for population research, especially for traits that are difficult to measure, like health data (Parker-Gaddis et al., 2012).The Regional Center of Informatics for Sustainable Animal Production (CRIPAS, for its acronym in Spanish), is a project developed in the Veterinary Medicine School (EMV, for its acronym in Spanish) of the Universidad Nacional (UNA, Costa Rica), aiming at the recording and storage of information from cattle production systems (Romero-Zúñiga et al., 2011). This initiative started in 1986 as an exchange project between the Universidad Nacional of Costa Rica and the University of Utrecht in the Netherlands. As part of the initial actions of the project, the Veterinary Automated Management and Production control Programme (VAMPP®), (Noordhuizen and Buurman, 1984; Pérez et al., 1989) was introduced to Costa Rica.

The VAMPP $®$ system, administered by CRIPAS, was originally created in the Netherlands and later adapted to the tropical conditions of Costa Rica (Baaijen and Pérez, 1995), where it has evolved over more than 30 years 
from a herd management program to a centralized information system. In order to achieve this transformation, the system has been committed to the highest quality and security standards of information technologies, such as a) confidentiality, avoiding the spread of sensitive information, b) integrity, the information is guaranteed not to be altered, and c) availability, avoiding the ban or retention of resources (Cabral-Ribeiro et al., 2009). The system also generates performance figures to support the tactic management of the farm comparing the values with the national database found in the EMV (Romero-Zúniga et al., 2011; Rojas-Campos et al., 2011; León-Hidalgo, 2015). Besides, information collected from the farms has allowed the production of numerous scientific publications for technical and professional fora.

Previous studies concluded that health data recorded through on-farm recording systems can be used for measuring disease incidence (Zwald et al., 2004a; Parker-Gaddis et al., 2012; Zwald et al., 2006) and for genetic selection (Zwald et al., 2004b). More recently, producer-recorded data have been used successfully to help implement genomic selection of health traits in US dairy cattle (Parker-Gaddis et al., 2014).

The possible effect of underreporting must be considered when using producer-recorded data for population analysis. For this purpose, several editing criteria for pre-selection of data have been proposed (Zwald et al., 2004a; Parker-Gaddis et al., 2012). Data quality filters are also required within the LIS to prevent the entry of erroneous information into the system (Rojas-Campos et al., 2011).

The VAMPP ${ }^{\circledR}$ system is currently the livestock information system most widely used in Costa Rica and is the official software of the main agribusiness milk company, Cooperativa de Productores de Leche Dos Pinos R.L (Romero-Zúñiga et al., 2011). It is also the source of data and support of the National Chamber of Milk Producers and the Dairy Farmers Improvement Association. Currently, the software is also used by livestock farms in Guatemala, Honduras, Nicaragua, El Salvador, Panama, Colombia, Bolivia and Mexico.

The objective of this study was to analyze the role of the VAMPP® system as a source of information for cattle population research over 32 years of evolution in Costa Rica.

\section{Material and methods}

\section{Structure of the Information System}

The study evaluated the evolution of the VAMPP® information system in Costa Rica, spanning the 32-year period from 1987 to 2018. The centralized database managed by the CRIPAS project (Romero-Zúñiga et al., 2011) was used. This database concentrates information from approximately 2285 dairy farms in Costa Rica (as of $12 / 31 / 2018)$.

At herd level, the personnel in charge upload to the VAMPP® system the different kinds of events (productive, reproductive and health-related); this information is stored and sent periodically to the industry, to the local cattle associations and to the Veterinary Medicine School (Universidad Nacional), on a voluntary basis (Figure 1).

The central database is dynamic; therefore, the herds can enter or exit the system at any time. Likewise, the recording and sending of information to the central database is voluntary, so that not all herds have data updated to the last year, nor they have data on every type of event.

The industry, mainly represented in this case by a large cooperative that gathers most of the local dairy farmers, promotes producers' access to the VAMPP ${ }^{\circledR}$ program and gives advice on the management and interpretation of the information produced by the program. Dairy factories owned by the cooperative also provide other services, such as milk quality analysis, and these data is entered into the system to be used both, for herd or individual cow evaluation.

The EMV is the entity that owns and distributes the VAMPP ${ }^{\circledR}$ program. The EMV provides initial training for new users of the program and seeks for the centralization and analysis of the information and the generation 


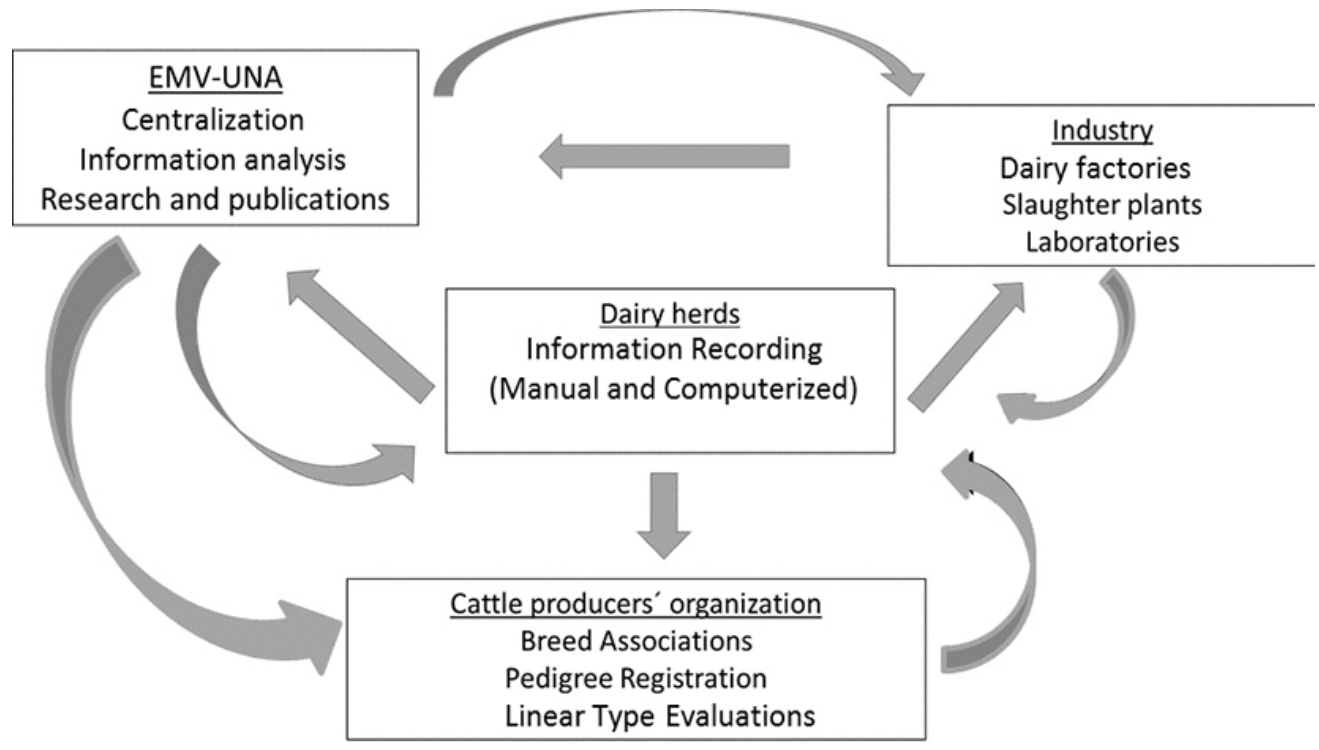

Figure 1. Flowchart of raw (straight lines) and processed (curved lines) information in the VAMPP® system. Costa Rica. Period 19872018.

Figura 1. Diagrama de flujo de información cruda (líneas rectas) y procesada (líneas curvas) en el sistema VAMPP®. Costa Rica. Periodo 1987-2018.

of reports and statistics, whether on an individual cow basis, or on a farm and population basis. At the same time the EMV makes use of this information for teaching and research purposes, which leads to the production of scientific material. EMV also plays a role by offering veterinary diagnostic services that can also be entered in the information system for later analysis.

The livestock associations, on the other hand, promote the genetic improvement of the different breeds through the organization of the breed herd-books and the realization of linear type evaluations. This information can also be added to the information system and be used later for genetic evaluation of bulls and cows. Results of these evaluations are made available to farmers with help of livestock associations.

\section{Statistical analysis}

A descriptive statistical analysis of information provided by the VAMPP® system was carried out. This analysis was performed to illustrate the role that the VAMPP® information system has played as a centralized database, providing support for research at the zone and breed levels within the country. The analysis focused on the following issues:

- Evolution of the number of herds entering the system since this was introduced by the CRIPAS project.

- Herd distribution according to the production system (specialized dairy or dual purpose).

- Herd distribution according to the agro-ecological zone (Holdridge, 1987).

- Summary of trends in the amount of information available in the database according to the type of event (reproduction, production or health-related events).

- Breeds within zone comparison of the two most frequently used efficiency parameters for dairy herds: 305-d milk yield and days open. 
- Time trends by breed for the 305-d milk yield.

- To evaluate the impact of VAMPP® in the field of scientific research, a summary of the academic products obtained with help of the system will be presented. A web search was performed using Google Academic engine to identify scientific publications and final graduation research connected to this system.

\section{Results}

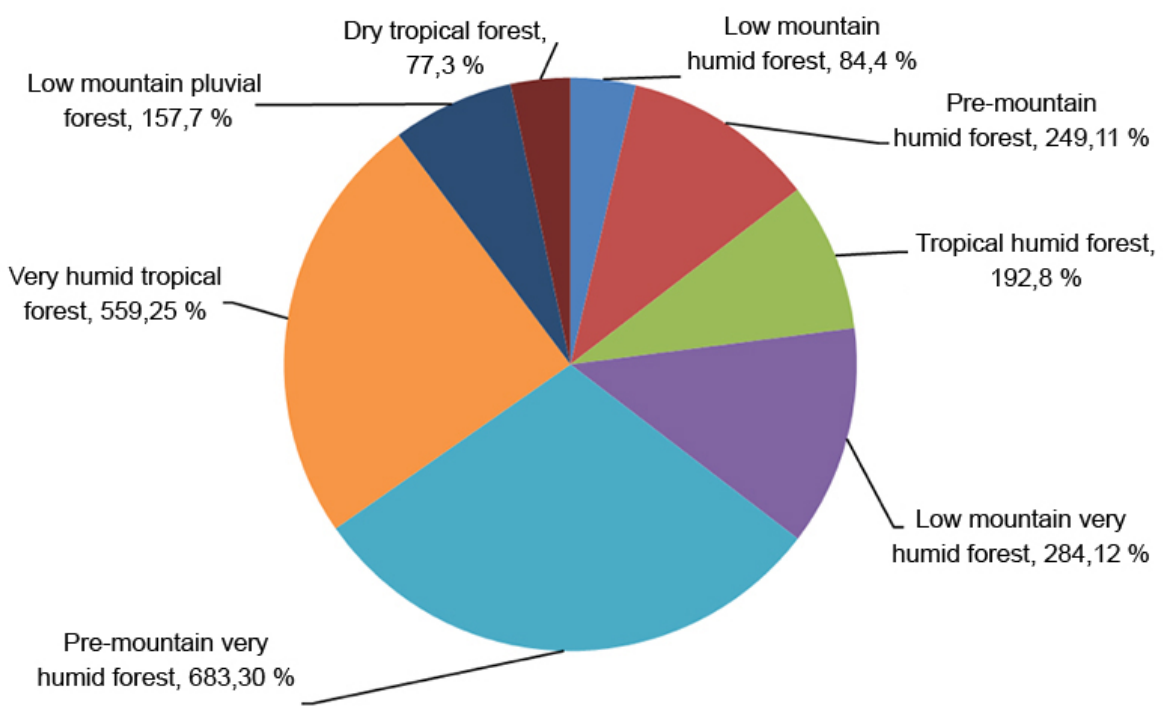

Figure 2. Number (\%) of herds included in the VAMPP® system according to the agro-ecological zone. Costa Rica. Period 1987-2018.

Figura 2. Número (\%) de hatos incluidos en el sistema VAMPP® según la zona agroecológica. Costa Rica. Periodo 1987-2018.

At the moment of this study, the centralized VAMPP® database contained information about 2285 herds, from which $2028(88.8 \%)$ corresponded to specialized dairies and $257(11.8 \%)$ to dual purpose operations. These herds were located in eight different agro-ecological zones, according to the system described by Holdridge (1987). Zones with the highest herd concentration were pre-mountain very humid forest (bmh-p) and very humid tropical forest (bmh-t), with $30 \%$ and $25 \%$ of the herds, respectively (Figure 2).

Since the beginning of the project in the late 1980s, the entry of farms into the system showed a non-linear growth pattern, with a higher rate of entry between the years 2002-2012 (Figure 3). For herds in the database, the number of adult cows was a highly-skewed variable with a mean of $124 \pm 245$ (median= 40 cows). Average number of follow up years for herds in the system was $9.4 \pm 7.9$ (median=7.0 yr). Herds with information updated to the last year (2018) represent about $26.8 \%$ of the total numbers of herds with information in the database.

Centralized database contained records on 404316 cows and 1249557 calvings. During the last 10 yr. the number of calving's records increased at a rate of $96000 \mathrm{yr}^{-1}$. There were 1098504 lactations and 16223260 milk test-day records, for an average of 14.7 records per lactation. For complete lactations (305 d) average number or test day records was $18.9 \pm 14.3$. Conversely, data on milk quality was scarce, with only $3.7 \%$ of lactations being recorded for fat and protein content, and $5.4 \%$ for somatic cell count. 


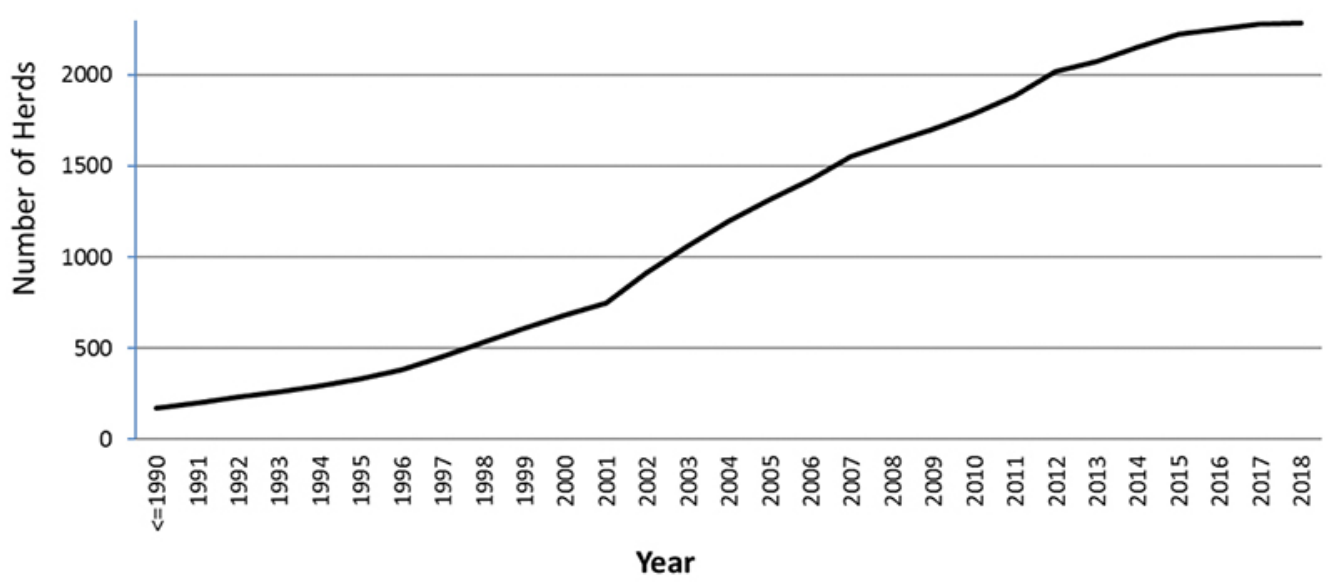

Figure 3. Evolution in the number of herds present in the centralized VAMPP ${ }^{\circ}$ database. Costa Rica. Period 1987-2018.

Figura 3. Evolución en el número de hatos presentes en la base de datos centralizada VAMPP®. Costa Rica. Periodo 1987-2018.

The most of calvings records in the information system came from the very humid pre-mountain (bmh-p, 25.8\%) and tropical (bmh-t, $27.2 \%$ ) forests, and most of them corresponded to breeds Holstein (35.8\%) and Jersey (26.1\%), or crosses HolsteinxJersey (22.9\%) (Figure 4). There was also information regarding other dairy and beef breeds, but in lower numbers.

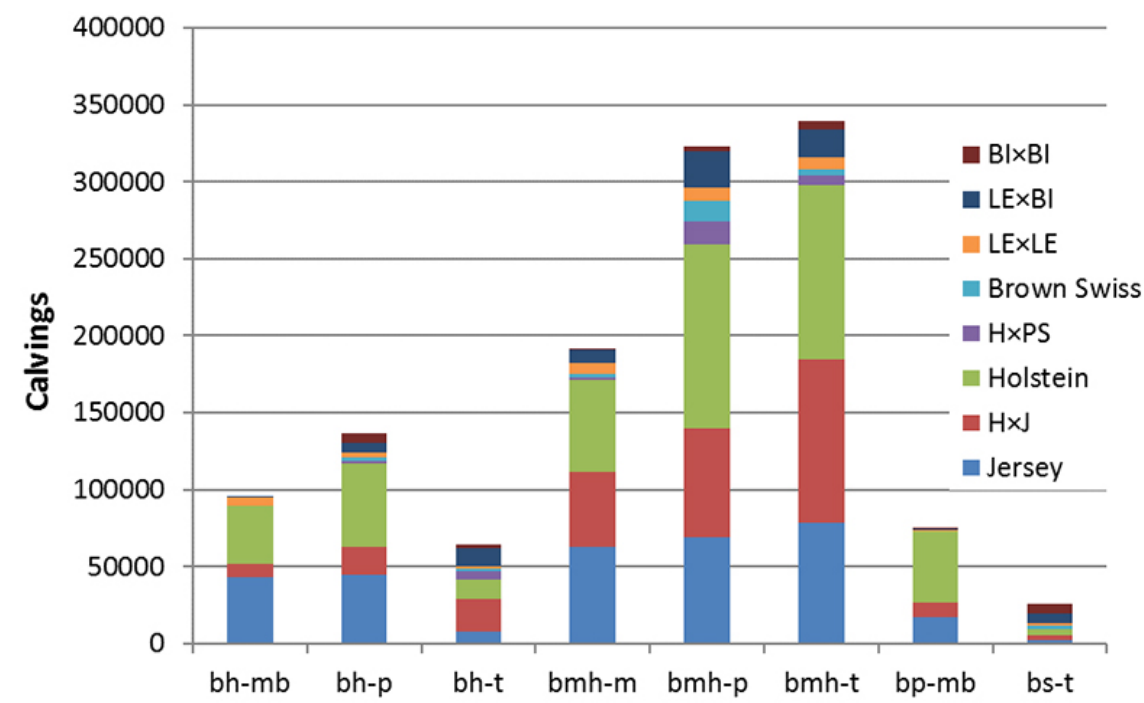

Figure 4. Number of calvings available in the database according to breed group [Holstein (H), Jersey (J), Brown Swiss (PS), other dairy breeds (LE), Bos indicus breeds (BI)], and the agro-ecological zones [low montane humid forest (bh-mb), pre-montane humid forest (bh-p), tropical humid forest (bh-t), very humid montane forest (bmh-m), very humid pre-montane forest (bmh-p), very humid tropical forest (bmh-t), low montane rain forest (bp-mb), tropical dry forest (bs-t]. Costa Rica. Period 1987-2018.

Figura 4. Cantidad de partos disponibles en la base de datos según grupo Racial [Holstein (H), Jersey (J), Pardo Suizo (PS), otras razas lecheras (LE), razas Bos indicus (BI)] y zona agroecológica [bosque húmedo montano bajo (bh-mb), bosque húmedo premontano (bhp), bosque húmedo tropical (bh-t), bosque muy húmedo montano (bmh-m), bosque muy húmedo premontano (bmh-p), bosque muy húmedo tropical (bmh-t), bosque pluvial montano bajo (bp-mb), bosque seco tropical (bs-t)]. Costa Rica. Periodo 1987-2018. 


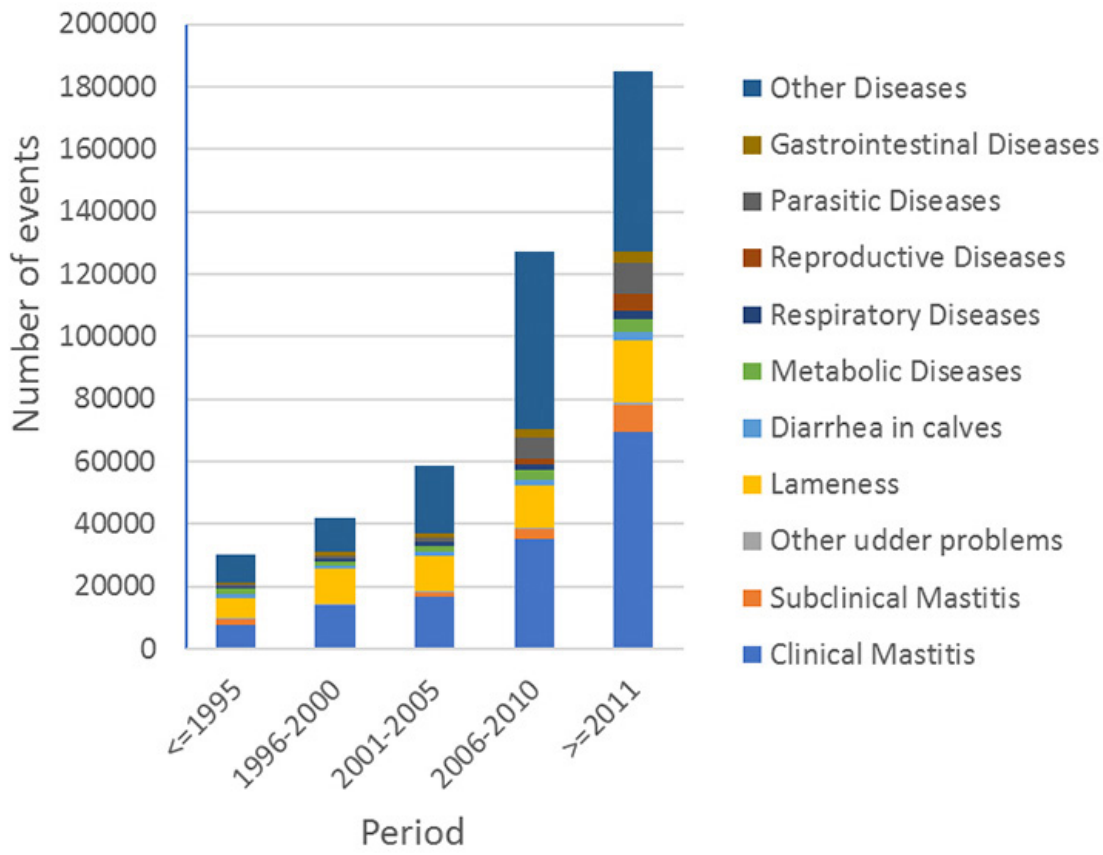

Figure 5. Number of health-related events entered in the VAMPP® database. Costa Rica. Period 1987-2018.

Figura 5. Cantidad de eventos relacionados con salud introducidos en la base de datos VAMPP®. Costa Rica. Periodo 1987-2018.

There were 443108 health-related events recorded in the database, most frequently related to mastitis (35.6\%) and lameness $(14.1 \%$ ), and to a much lesser extent reproductive diseases (Figure 5). Less common infectious diseases (stomatitis, anaplasmosis, leptospirosis) were pooled in one group as "other diseases", with a frequency of $35.4 \%$. Other health events (respiratory, metabolic, gastrointestinal, etc) were available in lower numbers. Number of healthrelated events recorded in the database increased in time, mainly due to the inclusion of new herds in the system.

The information available has been used to obtain population statistics by breed and zone for different productive and reproductive parameters, such as days open (Figure 6). Performance of different breeds within the same zone, or the same breed in different zones, can be appreciated. For example, a consistent difference of about 20 days open less in the Jersey breed compared with the Holstein breed is observed for the three zones (bmh_t, bmh_p, bmh_m). In the lowest and hottest zone (bmh_t) there were up to 8 more days open for Holstein and Jersey in comparison with the highest and coolest zone (bmh_m). Days open in the Holstein $\times$ Jersey cross were lower than the average of parental breeds.

Similar appreciations can be obtained regarding milk production per lactation (Figure 7), where the Holstein breed presents a marked superiority on the three agro-ecological zones. Differences up to $2000 \mathrm{~kg}$ can be observed amongst the different breeds within the same agro-ecological zone. In the same way, the yield of the Holstein breed in a low zone (bmh_t) was almost $1000 \mathrm{~kg}$ less than in the intermediate zone (bmh-p).

Trends in time can also be explored (Figure 8). For example, a clear increase in milk production during the period from 1987 to 2018 was appreciated; this was more noticeable in the case of the Holstein breed, which showed an increase from $5000 \mathrm{~kg}$ for cows born in 1987 up to $8000 \mathrm{~kg}$ for cows born on 2014, which means an 


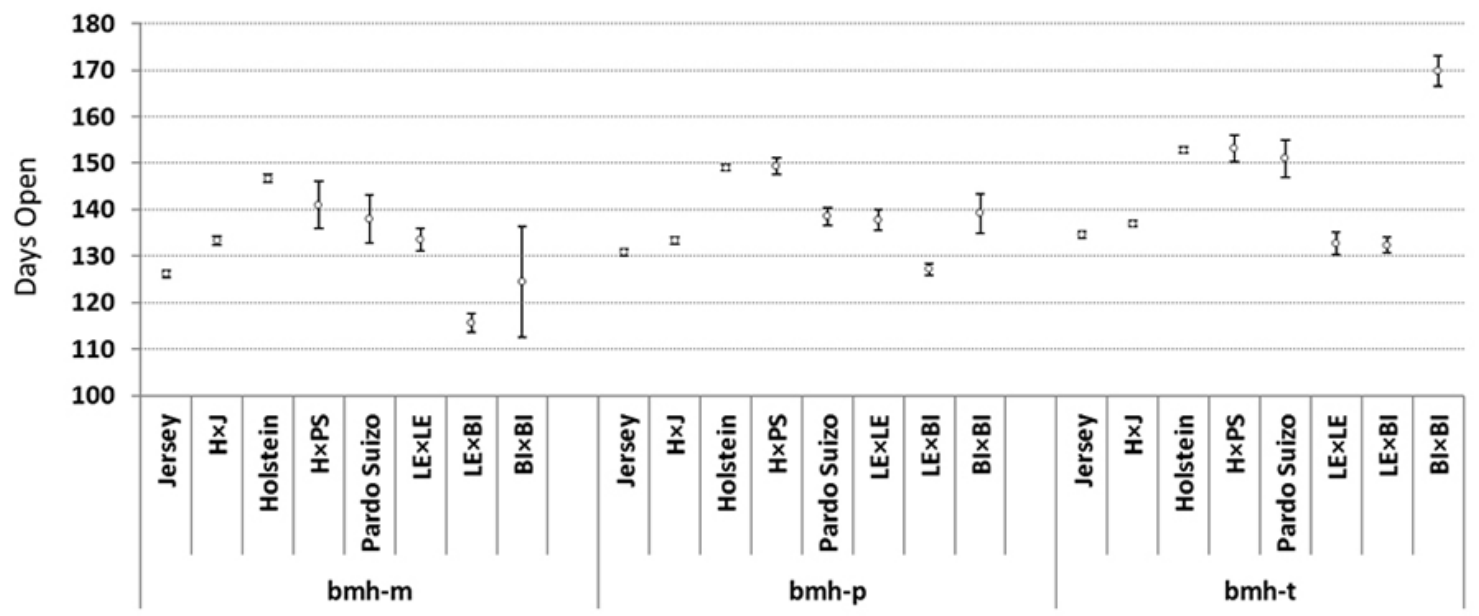

Breed within zone

Figure 6. Days open (mean and $95 \%$ confidence interval) for the different breed groups [Holstein (H), Jersey (J), Brown Swiss (PS), other dairy breeds (LE), Bos indicus breeds (BI)] in the agroecological areas: very humid montane forest (bmh-m), very humid premontane forest (bmh-p), and very humid tropical forest (bmh-t). Costa Rica. Period 1987-2018.

Figura 6. Días abiertos (promedio e intervalo de confianza $95 \%$ ) para diferentes grupos raciales [Holstein (H), Jersey (J), Pardo Suizo (PS), otras razas lecheras (LE), razas Bos indicus (BI)] en las zonas agroecológicas: bosque muy húmedo montano (bmh-m), bosque muy húmedo premontano (bmh-p) y bosque muy húmedo tropical (bmh-t). Costa Rica. Periodo 1987-2018.

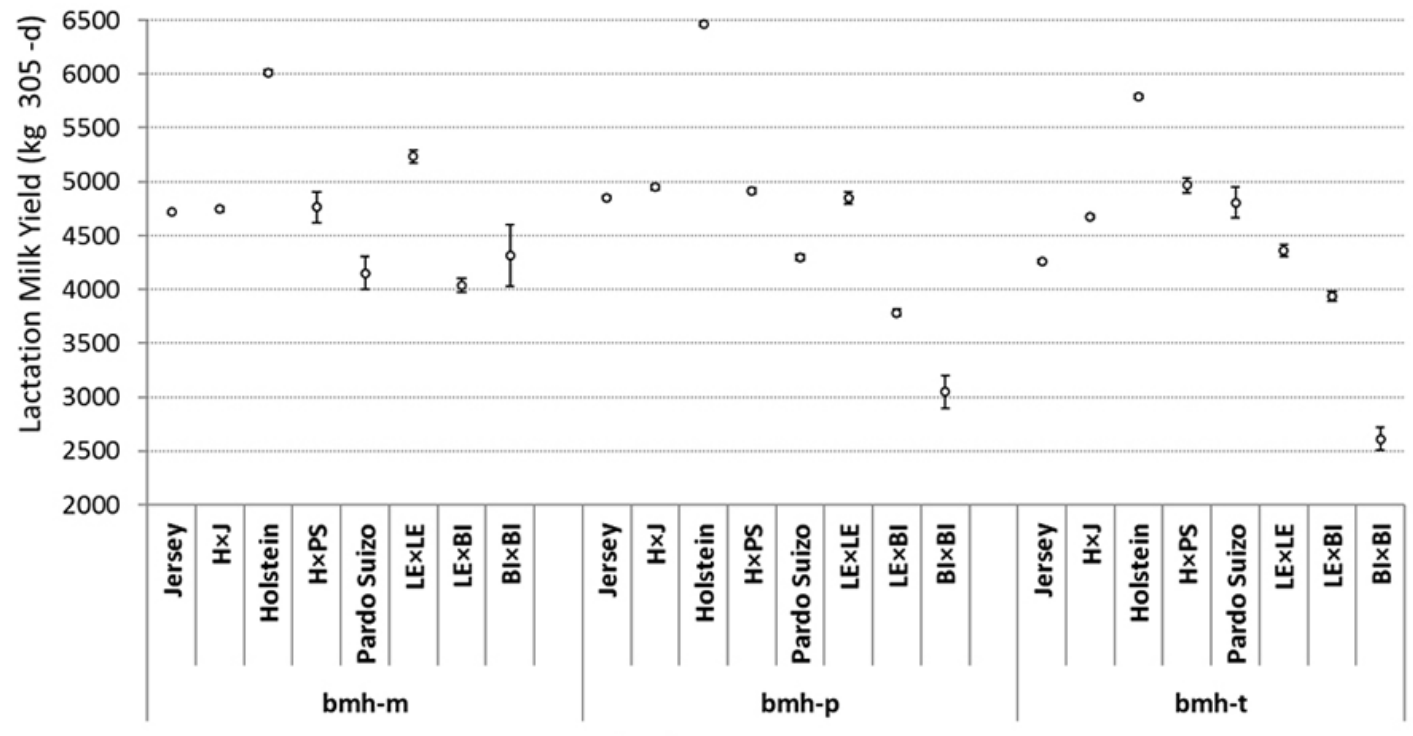

Breed within Zone

Figure 7. Milk production per lactation ( $\mathrm{kg}$, mean and $95 \%$ confidence interval) for the different breed groups [Holstein $(\mathrm{H})$, Jersey (J), Brown Swiss (PS), other dairy breeds (LE), Bos indicus breeds (BI)] in the very humid montane forest(bmh-m), very humid premontane forest (bmh-p), and very humid tropical forest (bmh-t) areas. Costa Rica. Period 1987- 2018.

Figura 7. Producción de leche por lactancia (kg, promedio e intervalo de confianza $95 \%)$ para diferentes grupos raciales [Holstein $(\mathrm{H})$, Jersey (J), Pardo Suizo (PS), otras razas lecheras (LE), razas Bos indicus (BI)] en las zonas bosque muy húmedo montano (bmh-m), bosque muy húmedo premontano (bmh-p) y bosque muy húmedo tropical (bmh-t). Costa Rica. Periodo 1987- 2018. 


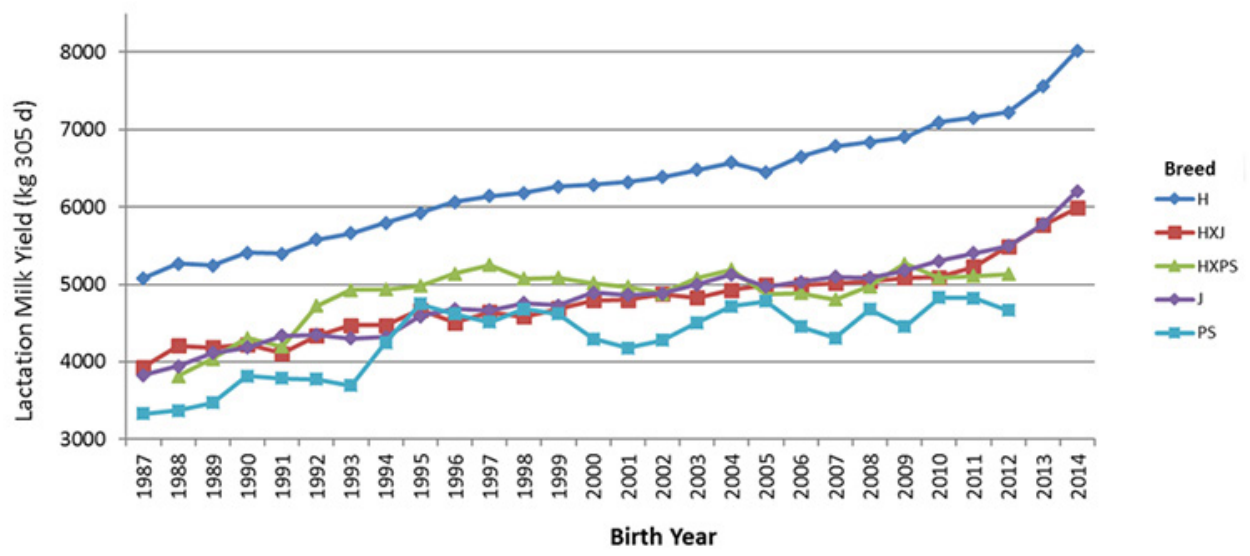

Figure 8. Average milk production at 305 days according to year and breed group [Holstein (H), Jersey (J), Brown Swiss (PS)]. Costa Rica. Period 1987-2018.

Figura 8. Promedio de producción de leche a 305 días según año y grupo racial [Holstein (H), Jersey (J), Pardo Suizo (PS)]. Costa Rica. Periodo 1987-2018.

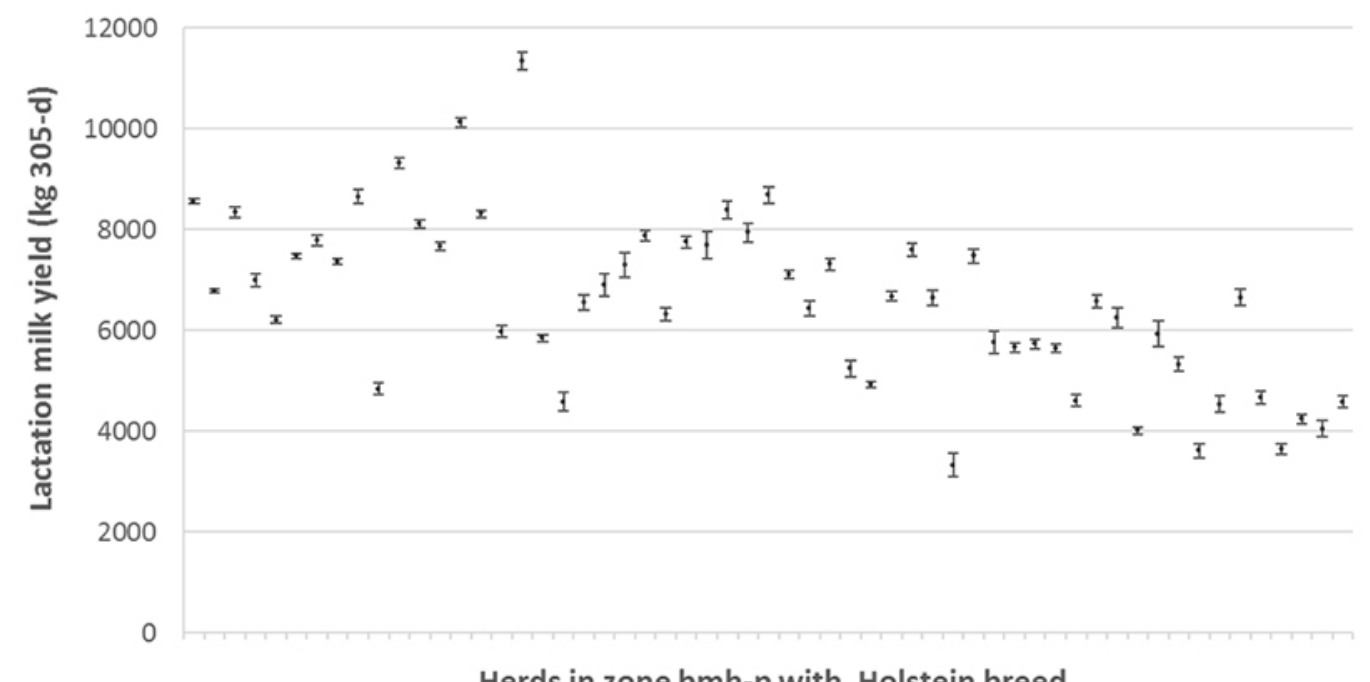

Herds in zone bmh-p with Holstein breed

Figure 9. Milk production per lactation ( $\mathrm{kg}$, mean and $95 \%$ confidence interval) for herds in the very humid pre-montane forest with the Holstein breed. Costa Rica, Period 1987-2018.

Figura 9. Producción de leche por lactancia (kg, promedio e intervalo de confianza $95 \%$ ) para hatos en la zona bosque muy húmedopremontano con la raza Holstein. Costa Rica, Periodo 1987-2018.

increase of $111 \mathrm{~kg} \mathrm{yr}^{-1}$ lactation ${ }^{-1}$. Similar trends can be obtained for the different productive and reproductive parameters, categorizing the information depending on how it is needed: at herd, breed, zone or national level.

The results of the population statistical analyses are available for the interested herds through a comparative module which is available within the same VAMPP ${ }^{\circledR}$ system. This module allows the herd owners to perform 
benchmarking (Figure 9), comparing the results of his/her herd against the rest of the population, using different grouping criteria, on a breed, zone or national level, according to his/her interest. The population estimates are updated annually, which encourages the participants to continue improving their herds. It is important to stress that individual identifications of the herds remain anonymous throughout the entire process.

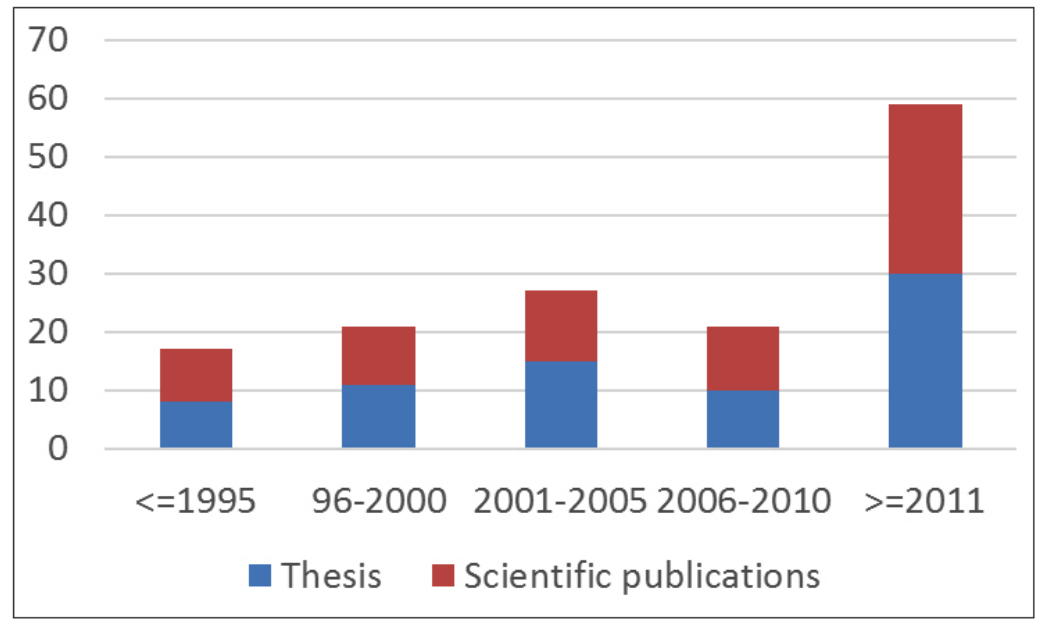

Figure 10. Number of theses and scientific publications produced from the VAMPP® database. Costa Rica. Period 1987-2018.

Figura 10. Número de tesis y publicaciones científicas producidas a partir de la base de datos VAMPP®. Costa Rica. Periodo 19872018.

From the academic point of view, the VAMPP® system has been used for the development of multiple graduation theses and on-farm research projects, which have culminated in scientific publications in areas of science such as veterinary medicine and agronomy. The database has been used to produce 39 and 35 graduate and postgraduate theses, respectively. A total of 71 publications were also identified in scientific journals with editorial advice (Figure 10). These publications deal with topics related to health, genetics, animal nutrition, characterization and analysis of livestock production systems, bioeconomic efficiency or evaluation of sustainability.

\section{Discussion}

The VAMPP® information system has shown a consistent progress in Costa Rica since its first implementation in the late 1980s (Figures 2 and 3). These results reflect an important adoption of this system, mainly within the group of specialized dairy farms $(n=2028)$. The central database has been able to capture approximately $74 \%$ of the herds that had entered their records in VAMPP $®$ at some point. According to the last census, there are 12974 dairy farms in Costa Rica (INEC, 2015), which means that the system has been able to collect information from approximately $16 \%$ of dairy herds in the country.

Several reasons can be proposed for the successful adoption within the dairy sector. Costa Rican authors that reviewed the VAMPP ${ }^{\circledR}$ in its early stages observe that the lack of scientific support was a constant for such a long time among producers that when offered the opportunity, they were willing to give the program and the methodology a chance (Baiijen and Pérez, 1995). This is reflected also in the high average of follow-up years (9.4 yr), a unique, or at least very rare case in Latin-American countries. 
The advances in the record and processing systems of electronic data provided strong support to the producers, placing the adequate information close to the users (Verstegen, 1997). Dairy farmers and the dairy industrial sector are generally recognized as developers of knowledge, triggering the innovations and the accuracy in livestock production (Udo and Brouwer, 1993; Eastwood et al., 2009). This is possibly also the reason why the system has not been equally successful in dual purpose farms.

Technology adoption is a mental process starting with the first acquisition of knowledge and ends when the individual includes the new tool in his/her working system (Salas-González et al., 2013). Different factors are influential in convincing farmers to use decision support tools, most important among them are usability, cost-effectiveness, performance, relevance to the user, and compatibility with compliance demands (Rose et al., 2016). Commercial applications tend to focus on solving daily farm tasks and aim to generate income for the farmers through better resource management and field operations planning (Fountas et al., 2015; Tsiropoulos et al., 2017). VAMPP ${ }^{\circledR}$ differs from most of the similar commercial systems locally available, because it was created and distributed by a public academic entity, in which scientific and social development objectives prevail over economic interests.

The interplay between the developers of LIS and end users should be favored by institutional actors such as universities and other organizations, which could act as facilitators, providing training to farmers and feedback to developers (Fountas et al., 2015). For the VAMPP ${ }^{\circledR}$ system, the continuous exchange of information between farmers and researchers has proven beneficial for both parts, promoting the continuous improvement of the system and the collection of high-quality information at lower cost (Verstegen, 1997; Rojas-Campos et al., 2011). Degree of adoption can be increased when suppliers co-design and work with farmers to ensure that new technology enables them to be in control and operates as an aid to achieving high quality stockmanship rather than a mechanism for profit maximization (Kaler and Ruston, 2019).

On dairy farms in Costa Rica, the average number per herd of females over 2 years of age was 15 (INEC, 2015), which is considerably lower than the average observed in the present study (mean=124). Previous studies have also reported a very strong bias for adoption and use of LIS from the largest producers due to a higher management level (Baaijen and Pérez, 1995; Tomaszewski et al., 2000). However, it should be considered that this average is skewed by a few herds with a high number of animals, while in reality $50 \%$ of herds have 40 or fewer adult cows.

The quantity and distribution of information by breed and zone (Figure 4) can be explained to a large extent by the relative abundance of the different dairy breeds within the country and by the environmental and/or physical adequacy of zones for dairy production. With respect to breeds, there has been a gradual substitution of the local cattle for Bos taurus breeds in dairy farms, enhanced by the use of artificial insemination, which is practiced locally since 1946 (Quirós-Quirós, 2006; Vargas-Leitón, 2012). For this reason, Holstein and Jersey breeds are currently dominant in local dairy farms.

Dairy herds of Costa Rica are mainly pasture-based production systems, located in areas ranging from 500 to 2500 m.a.s.l, with average temperatures ranging between 18 and $30{ }^{\circ} \mathrm{C}$ and precipitation levels that go from 500 to $3500 \mathrm{~mm}$ per year (Vargas-Leitón et al., 2013). These are the conditions prevailing in zones with humid (very humid) pre-mountain (tropical) forest, where pasture production is guaranteed throughout the entire year.

Furthermore, most of the herds that adopt the VAMPP ${ }^{\circledR}$ are located in the hills surrounding the central valley or in the flatter areas of the northern zone of the country, in both cases with immediate access to large populated areas, where input suppliers and markets are found. A previous study conducted on 1350 dairy herds from the same areas in Costa Rica, reported an average distance of $12.2 \pm 7.8 \mathrm{~km}$ from nearest populated area, $11 \pm 10.9 \mathrm{~km}$ from agro-veterinary warehouses, $19.4 \pm 10.9 \mathrm{~km}$ from milk collection centers and $0.22 \pm 0.49 \mathrm{~km}$ of neighborhood routes (Guillén-Gámez, 2015).

The large amount of data that has been collected with help of the VAMPP® system has proven to be very useful for research in local population. The study of animal performance directly in the production sites is essential 
for a more comprehensive understanding of the productive processes. Cattle population research has been an essential tool in different areas of animal production, such as epidemiology and animal breeding. In this sense, farm-based LIS provides an effective and low-cost source of information for population research, especially for traits that are difficult to measure, like health data (Parker-Gaddis et al., 2012). The value of the information is influenced by the nature and quantity of the data (Cornou and Kristensen, 2013). Basically, it has value only if it leads to a specific action and reduces the uncertainty in decision making (Kristensen et al., 2012). In this study, marked differences were observed regarding the type and number of events registered in the VAMPP ${ }^{\circledR}$ system. The information regarding calving and service events is by far the most complete, which is expected given that these data are mandatory and essential for the proper functioning of the system. Day-to-day activities and action lists for the farmer are based in accurate reproductive records, therefore these constitute the primary and decisive event to reach a higher efficiency (Cuevas-Reyes et al., 2013).

An approximate of $88 \%$ of calvings in the database have milk production records associated, which suggest that this is also a variable of primary importance in these dairy herds. The average number of test day records per lactation (14.6) was high. The proliferation of automatic milk weighing systems fully integrated with LIS has undoubtedly facilitated the collection of this data. Milk production records of individual cows are essential for within-herd selection and are also used to implement differential management in the herd (Vargas-Leitón, 2012; 2013).

Since 2008, this information system has provided the basis for bi-annual genetic evaluations, which allowed obtaining the estimated genetic potential for the animals in the population (Vargas-Leitón, 2013) as well as to estimate genetic parameters for important traits in the local population (Vargas-Leitón and Romero-Zúñiga, 2010; Aguirre-Valverde et al., 2013a; 2013b; Mora et al., 2016; Saborío-Montero et. al., 2018). The results of these evaluations are sent back to the herds through the internet and technical publications (Vargas-Leitón, 2013).

On the other hand, recording of milk quality at the individual level is not yet a frequent practice in these dairies, as shown by our results, despite the payment system is based in milk solids content, with a penalty for high bacterial and somatic cell counts (Vargas-Leitón and Cuevas-Abrego, 2009). This is likely due to logistics involved in the collection of individual samples, and further cost of processing.

In the case of dairy farms, mastitis and lameness, together with reproductive diseases, are the most frequent health problems, and constitute the main reasons for the elimination of cows in the herds, with large economic impact for the dairy sector (Mora et. al., 2015; Solano-López et al., 2018). Therefore, it is not surprising that these are also the health events more frequently reported in the VAMPP® database (Figure 5). The VAMPP ${ }^{\circledR}$ database has been used successfully to investigate environmental and genetic factors that affect important health problems, like mastitis (Mora et al., 2015; 2016), lameness (Solano-López et al., 2018) or milk fever (Saborío-Montero et al., 2017; 2018).

Farm-based information systems can also play an important role for the optimization of production systems. For dairy farmers, it is important to know the performance of different breeds within zone for variables that are of primary importance, such as days open and milk yield (Figures 6 and 7). In this sense, the information collected has pointed out where the Bos taurus pure breeds have lead with the best production averages, but not the most efficient reproductive traits. Even though the animals, as individuals, are the potential value for making decisions (Verstegen, 1997), the operations work as a company, so it is necessary to have a full overview; in other words, the population analysis is very important.

Being able to assess trends over time (Figure 8) is also important to measure the impact of breeding and management strategies. In this way, the Costa Rican database generated through VAMPP ${ }^{\circledR}$ has helped the farms in defining the type of cow and production system which adapts better to local markets and grazing conditions. The comparison between herds within a zone for a given breed (Figure 9) is another way to promote continuous improvement, since it allows producers to have a better picture of what can be achieved under similar conditions.

At this respect, the information provided by the VAMPP ${ }^{\circledR}$ system has also been used to create models that simulate farm production processes and to analyze variables that affect technical and economic efficiency in dairy 
farms (Vargas-Leitón and Cuevas-Abrego, 2009; Vargas-Leitón et al., 2012; 2015; Guillén-Gámez, 2015). The integration of the VAMPP ${ }^{\circledR}$ database with other databases from different sources, such as the industry (VargasLeitón et al., 2013), geographical information systems (Guillén-Gámez, 2015) or climate data (Ruiz-Jaramillo, 2017), has also been possible with very positive results.

There has been a large impact of the VAMPP ${ }^{\circledR}$ system on cattle population research, as shown by the considerable amount of scientific literature produced in the last 30 years (Figure 9). The value of producer-recorded data for population research in areas such as epidemiology and genetics has also been acknowledged in previous studies (Zwald et al., 2004a; Parker-Gaddis et al., 2012; 2014), however, examples of successful implementation are scarce, especially in developing countries.

Previous studies have shown that incidence rates of health events obtained from producer-recorded data fell within the range of those found in literature; however, they were generally lower than the mean incidence of literature reports, especially for less common diseases (Parker-Gaddis et al., 2012). This may partially be due to underreporting by dairy farmers who record disease events only when a treatment or other intervention is required (Parker-Gaddis et al., 2012).

Certainly, underreporting must be taken into account when analyzing producer-recorded data, but should never be a reason to reject their use. In this sense, several editing criteria for pre-selection of data have been proposed (Zwald et al., 2004a; Parker-Gaddis et al., 2012). Data quality filters are also required within the LIS to prevent the entry of erroneous information into the system. As an example, the VAMPP® system has approximately 2000 internal controls for consistency of the data (Rojas-Campos et al., 2011), providing a database of high reliability. For genetic analysis, reliable genealogical information is indispensable, which is also achieved by data entry filters and revision of genealogical records for consistency.

\section{Conclusion}

The VAMPP@ system, besides its primary role as LIS to optimize management in dairy herds, has given a strong impulse to the improvement of on-farm research, teaching programs, institutional and disciplinary cooperation, regional networking, and to a better linkage with the productive sector.

LIS based on producer recorded data are a valuable source of information which otherwise would be very expensive and difficult to obtain. LIS can be used as a basis for the development of research in various fields such as health, nutrition or genetics. In this sense, VAMPP ${ }^{\circledR}$ is one of the few successful examples of livestock information systems, administered at the farm level, that are used for population analysis and decision making. In this process, producers can also benefit from the exchange of information and experiences among themselves and with developers of LIS.

Although VAMPP® is a system managed at the herd level it has proven to be very useful at higher levels, such as producer cooperatives, breed associations, or government institutions dealing with the dairy sector. The system has also proven to be a good option for developing countries, such as Costa Rica, where economic resources for development of centralized information systems are very limited.

\section{Cited literature}

Aguirre-Valverde, J., B. Vargas-Leitón, y J.J. Romero-Zúñiga. 2013a. Efecto de la endogamia sobre parámetros productivos en vacas Holstein y Jersey de Costa Rica. Agron. Costarricense 37:31-44.

Aguirre-Valverde, J., B. Vargas-Leitón, y J.J. Romero-Zúñiga. 2013b. Efectos de la endogamia sobre parámetros reproductivos en vacas Holstein y Jersey de Costa Rica. Agron. Mesoam. 24:245-255. doi:10.15517/AM.V24I2.12523 
Baaijen, M., and E. Pérez. 1995. Information technology in the Costa Rican dairy sector: A key instrument in extension and on-farm research. Agric. Hum. Values 12:45-51. doi:10.1007/BF02217296

Cabral-Ribeiro, P.C., A.J. Scavarda, M.O. Batalha, and D. Bailey. 2009. Application of an IT evaluation method: Case studies in American ranches. Int. J. e-Bus. Manag. 3:20-34. doi:10.3316/IJEBM0302024

Cornou, C., and A.R. Kristensen. 2013. Use of information from monitoring and decision support systems in pig production: Collection, applications and expected benefits. Livest. Sci. 157:552-567. doi:10.1016/j.livsci.2013.07.016

Cuevas-Reyes, V., J. Baca-del-Moral, F. Cervantes-Escoto, J.A. Espinosa-García, J. Aguilar-Ávila, y A. Loaiza-Meza. 2013. Factores que determinan el uso de innovaciones tecnológicas en la ganadería de doble propósito en Sinaloa, México. Rev. Mex. Cienc. Pecu. 4:31-46.

Eastwood, C.R., D.F. Chapman, and M.S. Paine. 2009. Farmers as co-developers of innovative precision farming systems. In: A. Bregt et al., editors, Proceedings of the $7^{\text {th }}$ European Federation of Information Technology in Agriculture Conference. European Federation of Information Technology in Agriculture, Wageningen, NLD. p. 585-591.

Fountas, S., G. Carli, C.G. Sørensen, Z. Tsiropoulos, C. Cavalaris, A. Vatsanidou, B. Liakos, M. Canavari, J. Wiebensohn, and B. Tisserye. 2015. Farm management information systems: Current situation and future perspectives. Comput. Electron. Agric. 115:40-50.

Guillén-Gámez, A.A. 2015. Asociación entre variables espaciales y eficiencia productiva en hatos lecheros usuarios del programa VAMPP- bovino- Costa Rica. Tesis M.Sc., Universidad Nacional, Heredia, CRI.

Holdridge, L.R. 1987. Ecología basada en zonas de vida. Trad. por H. Jiménez-Saa. IICA, San José, CRI.

INEC (Instituto Nacional de Estadística y Censos). 2015. VI censo nacional agropecuario: Resultados generales. Instituto Nacional de Estadística y Censos, San José, CRI.

Kaler, J., and A. Ruston. 2019. Technology adoption on farms: Using Normalisation Process Theory to understand sheep farmers' attitudes and behaviours in relation to using precision technology in flock management. Prev. Vet. Med. 170:104715. doi:10.1016/j.prevetmed.2019.104715

Kristensen, A.R., L. Nielsen, and M.S. Nielsen. 2012. Optimal slaughter pig marketing with emphasis on information from online live weight assessment. Livest. Sci. 145:95-108. doi:10.1016/j.livsci.2012.01.003

León-Hidalgo, H. 2015. Rol de la gestión de datos en la ganadería ecoeficiente. UTN Informa 74:76-81.

Mora, M.G., B. Vargas, J.J. Romero, y J. Camacho. 2015. Factores de riesgo para la incidencia de mastitis clínica en ganado lechero de Costa Rica. Agron. Costarricense 39:77-89.

Mora, M.G., B. Vargas, J.J. Romero, y J. Camacho. 2016. Efecto de factores genéticos y ambientales sobre el recuento de células somáticas en ganado lechero de Costa Rica. Agron. Costarricense 40:7-18. doi:10.15517/RAC.V40I2.27346

Noordhuizen, J., and J. Buurman. 1984. VAMPP: a veterinary automated management and production control programme for dairy farms (the application of MUMPS for data processing). Vet. Quarter. 6(2):66-72. doi:10.1080/01652176.1984.969 3914

Parker-Gaddis, K.L., J.B. Cole, J.S. Clay, and C. Maltecca. 2012. Incidence validation and relationship analysis of producer recorded health event data from on-farm computer systems in the United States. J. Dairy Sci. 95:5422-5435. doi:10.3168/ jds.2012-5572

Parker-Gaddis, K.L., J.B. Cole, J.S. Clay, and C. Maltecca. 2014. Genomic selection for producer-recorded health event data in US dairy cattle. J. Dairy Sci. 97:3190-3199. doi:10.3168/jds.2013-7543 
Pérez, E., M.T. Baayen, E. Capella, and H. Barkema. 1989. Development of a livestock information system for Costa Rica. In: $\mathrm{H}$ : Kuil et al., editors, Proceedings $4^{\text {th }}$ International Conference of the Institute of Tropical Veterinary Medicine, Livestock production and diseases in the tropics. Institute of Tropical Veterinary Medicine, Utrecht, NED. p. 221-224.

Pérez, A., M. Milla, y M. Mesa. 2006. Impacto de las tecnologías de la información y la comunicación en la agricultura. Cul. Trop. 27:11-17.

Quirós-Quirós, E. 2006. Historia de la ganadería bovina en Costa Rica. StudyLib, ESP. https://studylib.es/doc/4783165/ (consultado 01 Jul. 2016).

Romero-Zúñiga, J.J., J. Rojas-Campos, y S. Estrada-König. 2011. El programa VAMPP bovino como herramienta de apoyo a la toma de decisiones en los sistemas de producción bovinos. Ventana Lechera 16(5):4-14.

Rojas-Campos, J., J.J. Romero-Zúñiga, y S. Estrada-König. 2011. VAMPP: Un programa en constante evolución. Ventana Lechera 16(5):47-56.

Rose, D.C., W.J. Sutherland, C. Parker, M. Lobley, M. Winter, C. Morris, S. Twining, C. Foulkes, T. Amano, and L.V. Dicks. 2016. Decision support tools for agriculture: towards effective design and delivery. Agric. Syst. 149:165-174. doi:10.1016/j.agsy.2016.09.009

Ruiz-Jaramillo, J.I. 2017. Variabilidad climática en las regiones norte, central y caribe y su asociación con variables productivas en fincas lecheras costarricenses. Tesis M.Sc., Universidad Nacional, Heredia, Costa Rica.

Saborío-Montero, A., B. Vargas-Leitón, J.J. Romero-Zúñiga, and J. Camacho-Sandoval. 2018. Additive genetic and heterosis effects for milk fever in a population of Jersey, Holstein $\times$ Jersey, and Holstein cattle under grazing conditions. J. Dairy Sci.101:9128-9134. doi:10.3168/jds.2017-14234

Saborío-Montero, A., B. Vargas-Leitón, J.J. Romero-Zúñiga, and J.M. Sánchez. 2017. Risk factors associated with milk fever occurrence in grazing dairy cattle. J. Dairy Sci.100:9715-9722. doi:10.3168/jds.2017-13065

Salas-González, J.M., J.A. Leos-Rodríguez, L.M. Sagarnaga-Villegas, y M.J. Zavala-Pineda. 2013. Adopción de tecnologías por productores beneficiarios del programa de estímulos a la productividad ganadera (PROGAN) en México. Rev. Mex. Cienc. Pecu. 4:243-254.

Solano-López, M., B. Vargas-Leitón, A. Saborío-Montero, y D. Pichardo-Matamoros. 2018. Factores genéticos y ambientales en lesiones podales del ganado lechero en Costa Rica. Agron. Mesoam. 29:123-140. doi:10.15517/ma.v29i1.28027

Tomaszewski, M.A., M.A.P.M. van-Asseldonk, A.A. Dijkhuizen, and R.B.M. Huirne. 2000. Determining farm effects attributable to the introduction and use of a dairy management information system in The Netherlands. Agric. Econ. 23:79-86. doi:10.1111/j.1574-0862.2000.tb00085.x

Tsiropoulos, Z., G. Carli, E. Pignatti, and S. Fountas. 2017. Future perspectives of farm management information systems In: S.M. Pedersen, and K.M. Lind, editors, Precision agriculture: Technology and economic perspectives, progress in precision agriculture. Springer International Publishing, Cham, SWE. p. 181-200. doi:10.1007/978-3-319-68715-5_9

Udo, H.M.J., and B.O. Brouwer. 1993. A computerised method for systematically analysing the livestock component of farming systems. Comp. Electron. Agric. 9:335-356. doi:10.1016/0168-1699(93)90050-B

Vargas-Leitón,B. 2012. Mejoramiento genético del ganado lechero: el contexto global y local. InfoHolstein 2012(Diciembre):6-14.

Vargas-Leitón, B. 2013. Mejoramiento genético: herramienta para incrementar la productividad del hato lechero. UTN Informa 66:6-14.

Vargas-Leitón, B., y M. Cuevas-Abrego. 2009. Modelo estocástico para estimación de valores económicos de rasgos productivos y funcionales en ganado lechero. Agrociencia 43:881-893. 
Vargas-Leitón, B., Y. Marín-Marín, y J.J. Romero-Zúñiga. 2012. Comparación bioeconómica de grupos raciales Holstein, Jersey y F1 Holstein×Jersey en la zona de vida Bosque muy Húmedo Premontano. Agron. Mesoam. 23:329-342. doi:10.15517/ AM.V23I2.6533

Vargas-Leitón, B., y J. Romero-Zúñiga. 2010. Efectos genéticos aditivos y no aditivos en cruces rotacionales entre razas lecheras. Agron. Mesoam. 21:223-234. doi:10.15517/AM.V21I2.4885

Vargas-Leitón, B., O. Solís-Guzmán, F. Saénz-Segura, y H. León-Hidalgo. 2013. Caracterización y clasificación de hatos lecheros en Costa Rica mediante análisis multivariado. Agron. Mesoam. 24:257-275. doi:10.15517/am.v24i2.12525

Vargas-Leitón, B., O. Solís-Guzmán, F. Saénz-Segura, y H. León Hidalgo. 2015. Eficiencia técnica en hatos lecheros de Costa Rica. Agron. Mesoam. 26:1-15. doi:10.15517/AM.V26I1.16886

Verstegen, J.A.A.M. 1997. Outlining economic modules for farm management information systems in Costa Rica: Report of a LEI-DLO mission to the Veterinary School of the National University of Costa Rica. Wageningen University and Research, Wageningen, NDL. https://library.wur.nl/WebQuery/wurpubs/fulltext/400407 (accessed Jul. 01, 2016)

Vilaseca, J., J. Torrent, y Á Díaz. 2002. La economía del conocimiento: paradigma tecnológico y cambio estructural. Un análisis empírico e internacional para la economía española. Working Paper Series WP02-003. Universitat Oberta de Catalunya, ESP. http://www.uoc.edu/in3/dt/20007/index.html (consultado 01 Jul. 2016).

Zwald, N.R., K.A. Weigel, Y.M. Chang, R.D. Welper, and J.S. Clay. 2004a. Genetic selection for health traits using producerrecorded data. I. Incidence rates, heritability estimates, and sire breeding values. J. Dairy Sci. 87:4287-4294. doi:10.3168/ jds.S0022-0302(04)73573-0

Zwald, N.R., K.A. Weigel, Y.M. Chang, R.D. Welper, and J.S. Clay. 2004b. Genetic selection for health traits using producerrecorded data. II. Genetic correlations, disease probabilities, and relationships with existing traits J. Dairy Sci. 87:42954302. doi.org/10.3168/jds.S0022-0302(04)73574-2

Zwald, N.R., K.A. Weigel, Y.M. Chang, R.D. Welper, and J.S. Clay. 2006. Genetic analysis of clinical mastitis data from on-farm management software using threshold models. J. Dairy Sci. 89:330-336. doi.org/10.3168/jds.S0022-0302(04)73574-2 